Ks. Mariusz SZRAM

(Lublin, KUL)

\title{
UDZIAE WIERNYCH ŚWIECKICH W FUNKCJACH WSPÓŁCZEŚNIE ZASTRZEŻONYCH KAPLANOM URZĘDOWYM ORAZ W STRUKTURACH INSTYTUCJONALNYCH KOŚCIOŁA W UJĘCIU ORYGENESA
}

Zachowane pisma Orygenesa, jak również relacje biograficzne o nim samym, zawierają pewne wzmianki, dotyczące możliwości sprawowania przez osoby świeckie pewnych funkcji zastrzeżonych w naszych czasach czlonkom stanu kapłańskiego oraz świadczące o udziale wiernych, także kobiet, w strukturach instytucjonalnych Kościoła zbliżonych do duchowieństwa. Teksty te odnoszą się do następujących zagadnień:

1) publiczne komentowanie Pisma św. na zgromadzeniu liturgicznym,

2) odpuszczanie grzechów, nakładanie pokuty i kierownictwo duchowe,

3) funkcje sprawowane przez prorokinie i diakonisy.

W niniejszym artykule dokonam analizy materiału źródłowego według podanego powyżej planu, starając się znaleźć odpowiedź na pytanie, jaki był i jaki być powinien, w opinii Orygenesa, ów udział osób świeckich w funkcjach postrzeganych dzisiaj zasadniczo jako kapłańskie lub do kapłańskich zbliżone.

1. Publiczne komentowanie Pisma św. na zgromadzeniu liturgicznym. Życie Orygenesa dostarcza świadectw o istniejącej w jego czasach możliwości publicznego komentowania Pisma św. przez osoby świeckie. Dowiadujemy się o tym ze słynnej biograficznej wzmianki w Historii kościelnej Euzebiusza, dotyczącej wydarzeń z młodości Orygenesa. Otóź w 215 r. Orygenes jako młody aleksandryjski katecheta świecki przebywał po raz pierwszy przez krótki czas w Cezarei Palestyńskiej. Biskupi Teoktyst z Cezarei i Aleksander z Jerozolimy zapragnęli wykorzystać obecność sławnego już wówczas znawcy Pisma św. i, jak to określa Euzebiusz, udzielili mu pozwolenia na publiczne wyjaśnianie tekstów biblijnych przed zgromadzeniem wiernych ${ }^{1}$. Spotkało się to z protestem biskupa Aleksandrii, Demetriusza, który w liście do biskupów palestyńskich napisał, że „nigdy nie słyszano, ani się za naszej działo pamięci,

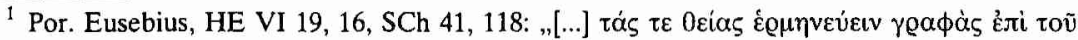

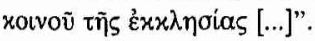


by laicy w obecności biskupów wygłaszali homilie"2. Z obronnego listu biskupów palestyńskich ${ }^{3}$ wynika jednak, że przynajmniej w niektórych Kościołach lokalnych świeccy, za zgodą biskupa, mieli prawo do publicznych wystąpień przed zgromadzeniem wiernych:

„Gdziekolwiek bowiem znajdują się ludzie zdolni, by braciom oddać przystugę, tam wszędzie święci biskupi proszą ich, by do ludu przemawiali. Tak na przykład w Larandach prosił Neron Euelpidę, w Ikonion Celsus Paulina, w Synadach Attikos Teodora"

Zgodnie z powyższym świadectwem świeccy, przynajmniej w niektórych Kościolach lokalnych w Palestynie i Azji Mniejszej, mieli prawo, za zgodą biskupa, komentować Pismo św., trudno jednak dociec, o jaki rodzaj zgromadzeń chodziło i jaki miały charakter owe wystąpienia. W każdym razie biskup aleksandryjski zrozumiał je jako rodzaj homilii i zdecydowanie potępil.

Zastanawiające jest sformułowanie Demetriusza o zakazie wygłaszania

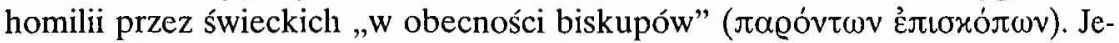
żeli przyjąć za obowiązujące również w Aleksandrii stanowisko Ignacego z Antiochii wyrażone w Liście do Smyrnian, to biskup przewodniczył Eucharystii, obrzędom udzielania chrztu i agapom ${ }^{5}$. Pozostaje kwestią otwartą, czy Demetriusz swoim stwierdzeniem wskazywał pośrednio na inny rodzaj zgromadzeń, bez udziału biskupa, podczas których mogły być ewentualnie możliwe wystąpienia świeckich, komentujących Pismo święte. Skądinąd wiadomo przecież, że świeccy byli katechetami i taką funkcję zlecił młodemu Orygenesowi ten sam biskup Demetriusz.

We własnych pismach Orygenesa nie spotykamy żadnych konkretnych wzmianek na temat głoszenia homilii przez osoby świeckie. Aleksandryjczyk przypomina jedynie, ze kapłaństwo wiernych, otrzymane na chrzcie, zobowiązuje wszystkich wiernych do studium Pisma świętego i do jego duchowego rozumienia ${ }^{6}$.

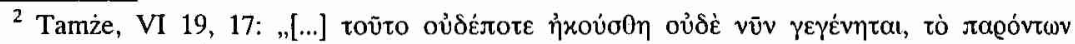

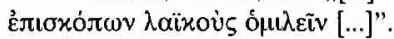

${ }^{3}$ List ten, którego fragment znamy tylko z krótkiego cytatu u Euzebiusza, Crouzel dałuje na czas konfliktu już po udzieleniu Orygenesowi święceń kapłańskich w 231 roku, por. H. Crouzel, Origéne, Paris 1985, 35.

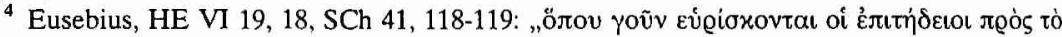

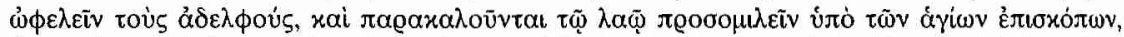

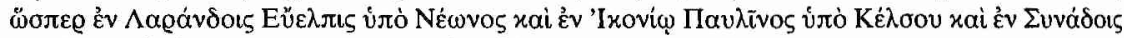

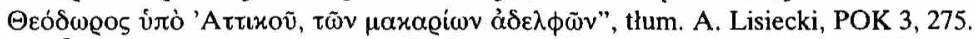

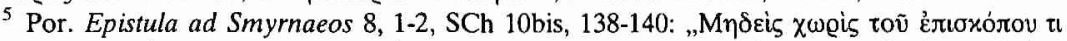

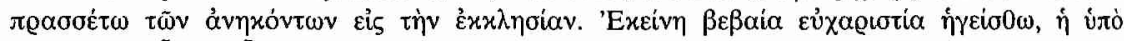

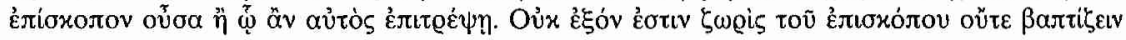

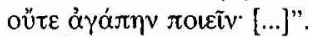

${ }^{6}$ Por. Origenes, In Leviticos hom. 6, 5, SCh 286, 288: „Potes enim et tu, ut saepe iam diximus, si studiis et vigiliis tuis huiuscemodi tibi praeparaveris indumenta, si te abluerit et mundum fecerit 
2. Odpuszczanie grzechów, nakladanie pokuty i kierownictwo duchowe. Dziela Orygenesa zawierają dyskusyjne fragmenty, dotyczące problemu odruszczania grzechów i nakładania grzesznikom pokuty ${ }^{7}$. W traktacie $O$ modlitwie znajdujemy następujące stwierdzenie:

„Kto działa pod tchnieniem Jezusa, jak Apostołowie, i przez swe owoce okazuje,

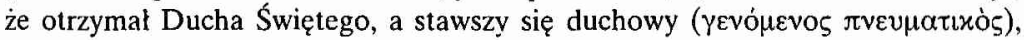
słucha natchnień Ducha jako Syn Boży, rozumnie działając we wszystkim, odpuszcza grzechy, które Bóg odpuszcza [...]":

Wypowiedź ta może sugerować, że władza odpuszczania grzechów przysługuje, zdaniem Orygenesa, każdemu prawdziwemu czlowiekowi duchowemu, żyjącemu w głębokiej łączności z Chrystusem, i tak rozumieli to zdanie Aleksandryjczyka dawniejsi teologowie, jak J. Döllinger czy A. Harnack. Dalszy fragment powyższego tekstu nie pozostawia jednak wątpliwości, że Orygenesowi chodzi tu nie o wszystkich ludzi duchowych, ale tylko o:

„[...] Apostolów i ich następców, kapłanów (į£єī) według obrazu wielkiego Arcykapłana, którzy otrzymali wiedzę o Bożym uzdrowieniu i z pouczenia Ducha Świętego wiedzą, za które grzechy należy składać ofiarę, kiedy i w jaki sposób"9.

W przekonanill, że według Orygenesa odpuszczenie grzechów i nałożenie pokuty zastrzeżone jest urzędowemu kapłanowi, utwierdza inny fragment z jego zaclıowanych dzieł. W Homiliach do Księgi Liczb czytamy:

„Jeśli grzeszy [...] człowiek świecki, sam nie może usunąć swego grzechu, lecz [...] potrzebuje kapłana, a nawet poszukuje kogoś znakomitszego [...] arcykapłana [czyli biskupa], aby uzyskać odpuszczenie grzechów"10.

sermo legis et unctio chrismatis et gratia in te baptismi incontaminata duraverit, si indutus fueris indumenti duplicibus litterae ac spiritus, si etiam dupliciter accingaris, ut carne et animo castus sis, si humerali operum et sapientiae rationali orneris, si etiam mitra tibi et lamina aurea, plenitudo scientiae Dei, caput coronet, scito te, etiamsi apud homines lateas et ignoreris, apud Deum tamen agere pontificatum intra animae tuae templum". Zob. M. Szram, Orygenes o kaptanistwie. Antologia tekstów, Olsztyn 1997, 28.

${ }^{7}$ Por. podstawową literaturę na ten temat: B. Poschmann, Die Sündenvergebung bei Origenes, Braunsberg 1912; tenże, Poenitentia secunda, Bonn 1940; P. Galtier, L'Eglise et la remission des péchés aux premiers siècles, Paris 1932; E.T. Latko, Origen's concept of Penance, Québec 1949; K. Rahner, La doctrine d'Origène sur la penitence, RSR 37 (1950) 47-97, 252-286, 422-456.

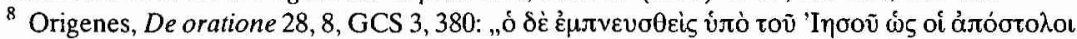

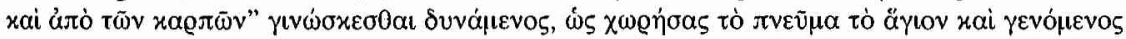

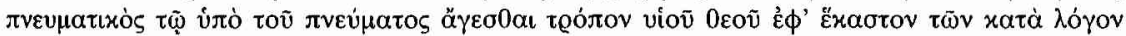

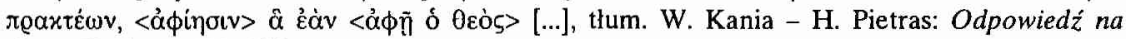
stowo, Kraków 1993, 208.

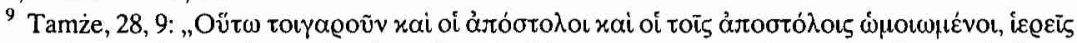

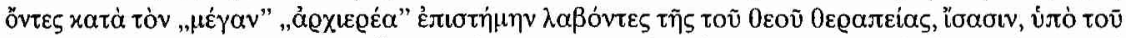

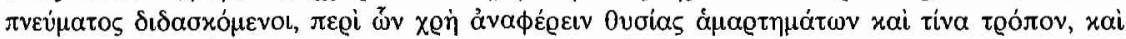

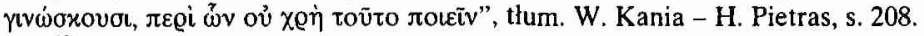

${ }^{10}$ Origenes, In Numeros hom. 10, 1, SCh 415, 270: .,Israhelita si peccet, id est laicus, ipse suum 
Natomiast w Homiliach do Księgi Kapłaniskiej Orygenes wymienia wprawdzie aż siedem sposobów otrzymania odpuszczenia grzechów, ale tylko ostatni $\mathrm{z}$ nich odpowiada sakramentowi pokuty $\mathrm{w}$ dzisiejszym rozumieniu, a udzielanie go stanowi przywilej kapłana. Dwa pierwsze sposoby - to chrzest i męczeństwo, cztery kolejne - to praktyka dobrych uczynków (rozdawanie jałmużny, wybaczanie przewinień, nawracanie grzeszników, obfitość miłosierdzia):

„Jest jeszcze siódmy sposób, aczkolwiek trudny i wymagający mozołu, odpuszczenie grzechów przez pokutę [...], gdy [grzesznik] nie wstydzi się wyznać swych grzechów kapłanowi Pana i szukać lekarstwa [...]"11.

Idealna sytuacja, zdaniem Orygenesa, zachodzi wówczas, gdy urzędowy kapłan, odpuszczający grzechy, jest rzeczywiście w swoim życiu pneumatykiem, czyli człowiekiem duchowym, dążącym do zjednoczenia z Chrystusem.

Powyższe wypowiedzi Aleksandryjczyka odnosiły się przede wszystkim do prywatnego wyznania grzechów i prywatnej pokuty, wystarczającej w przypadku grzechów lekkich i możliwej do wielokrotnego powtarzania. Natomiast grzechy ciężkie wymagały ówcześnie oficjalnego okresowego wyłączenia ze wspólnoty i odbycia pokuty publicznej, która mogła być podjęta jeden raz w życiu. Cała ta procedura wraz z odpuszczeniem grzechów i ponownym przyjęciem do wspólnoty musiała dokonywać się pod przewodnictwem biskupa ${ }^{12}$.

O ile odpuszczenie grzechów i nałożenie pokuty nie mogło być dokonane, w przekonaniu naszego autora, przez człowieka duchowego, nie będącego urzędowym kapłanem, o tyle taki człowiek mial prawo spełniać rolę doradcy duchowego. Korzystając z charyzmatów otrzymanych od Ducha Świętego, mógł on prywatnie lub publicznie zachęcać i pouczać grzesznika, uświadamiając mu stan jego duszy, z którego ów nie zdawał sobie sprawy ${ }^{13}$. Ponadto Orygenes pozostawil świadectwo istnienia w jego czasach swoistych „strażników obyczajów", czyli grona wiernych świeckich, wspomagających biskupa, których zadaniem było czuwanie nad postępowaniem katechumenów, upominanie ich i ewentualne donoszenie biskupowi o popełnionych przez nich wykroczeniach $^{14}$.

non potest auferre peccatum, sed requirit levitam, indiget sacerdote, immo potius et adhuc horum aliquid eminentius quaerit: pontifice opus est, ut peccatorum remissionem possit accipere", thum. S. Kalinkowski, PSP 34/1, 92.

${ }^{11}$ In Leviticos hom. 2, 4, SCh 286, 110: „Est adhuc et septima, licet dura et laboriosa, per paenitentiam remissio peccatorum [...] cum non erubescit sacerdoti Domini indicare peccatum et quaerere medicinam $[\ldots]^{\prime \prime}$.

12 Por. tamże, 15, 2, SCh 287, 256: „In gravioribus enim criminibus semel tantum paenitentiae conceditur locus [...]"; tamże, 14, 3. Zob. J. Daniélou, Origène, Paris 1948, 82-83; Rahner, art. cyt., s. 257.

13 Por. Rahner, art. cyt., s. 260.

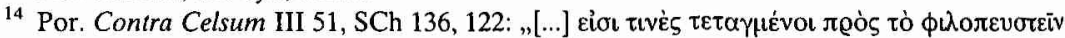

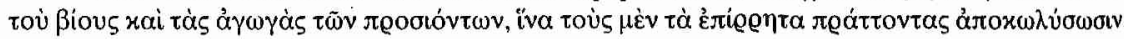


3. Funkcje sprawowane przez kobiety - prorokinie i diakonisy. Pisma Orygenesa zawierają szereg interesujących informacji na temat funkcji, które mogły być sprawowane w Kościele przez kobiety: dziewice, wdowy, prorokinie i diakonisy. Zgodnie ze świadectwem Tradycji apostolskiej Hipolita, Konstytucji Apostolskich oraz kanonu 19. Soboru Nicejskiego I, trzy spośród wymienionych wyżej grup kobiet - dziewice, wdowy i diakonisy - tworzyły rodzaj kościelnych instytucji (ordo), nie należaly jednak do duchowieństwa ${ }^{15}$. Orygenes potwierdza istnienie w Kościele wszystkich czterech grup, wprowadza jednak pewne ograniczenia w zakresie sprawowanych przez nie funkcji. W niniejszym arty'kule pomijam kwestię dziewic i wdów, a skupiam się jedynie na prorokiniach i diakonisach, których posługa była pod pewnymi względami zbliżona do tej, jaką speiniali prezbiterzy i diakoni.

O istnieniu prorokiń w początkach Kościoła wspominaja już kanoniczne Dzieje Apostolskie, wymieniające cztery dziewice-prorokinie, córki ewangelisty Filipa z Cezarei $(21,8-9)$, a także apokryfy Nowego Testamentu (Akta Pawta). O kobietach i mężczyznach obdarzonych charyzmatami Ducha Świętego mówi później Justyn ${ }^{16}$, a o prorokiniach mających widzenia w ekstazie $\operatorname{Tertulian}^{17}$. Orygenes ustosunkowuje się do kwestii kobiet prorokujących

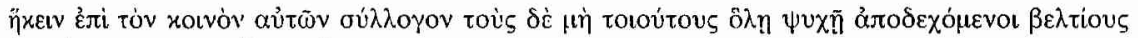

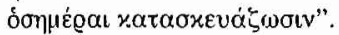

${ }^{15}$ Por. Traditio Apostolica 10; Constitutiones Apostolorum VIII 28, 6, SCh 336, 230:

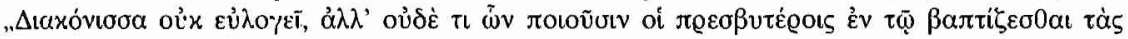

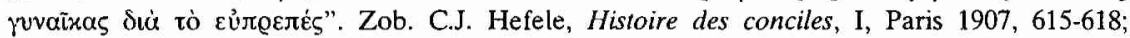
W. Myszor, Europa. Pierwotne chrześcijaństwo. Idee i życie społeczne chrześcijan (II i III wiek), Warszawa 1999i2000, 142-148. Ze względu na obowiązki zbliżające wdowy do członków hierarchii, Orygenes wymieniał je często razem z biskupami, prezbiterami i diakonami: „Prócz [...] ogólnych powinności ma jeszcze szczególne zobowiązania korzystająca z opieki Kościoła wdowa, inne diakon, jeszcze inne prezbiter, na biskupie spoczywa szczególnie ciężki obowiązek [...]" (Origenes, De oratione 28, 4, tum. W. Kania - H. Pietras, s. 205; tenże, Commentarium in Lucam 17, 10). Do obowiązków tych zalicza nasz autor przede wszystkim nauczanie moralne i duchowe, skierowane do chrześcijańskich kobiet. O wyjątkowej pozycji zajmowanej w Kościele przez wdowy świadczy np. wzmianka Tertuliana w De pudicitia 13, 7, o tym, że grzesznicy, prosząc o pojednanie z Kościołem, musieli skłonić się w obecności całego zgromadzenia przed wdowami i przed prezbiterami. Również Tertulian informuje, że podczas celebracji Eucharystii wdowy zajmowały specjalne miejsca (De virginibus velandis 9,3 ) i stały półkolem wokól biskupa (Exhortatio in castitatem 11 , 2). $\mathrm{Z}$ innych źródel dowiadujemy się o ich obowiązkach: modlitwie, szczególnie za chorych i grzeszników (1 Tm 5, 5; Hippolytus, Traditio Apostolica 10 i 23; Didascalia et Constitutiones Apostolorum III 5, 2; 8, 1-3), oraz poście (Hippolytus, Traditio Apostolica 23).

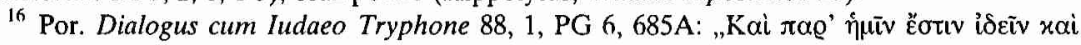

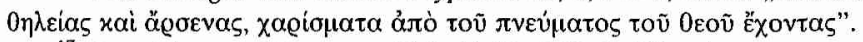

17 Por. Adversus Marcionem V 8,11-12, CCL 1, 688: „Aeque praescribens silentium mulieribus in Ecclesia, ne quid discendi duntaxat gratia loquantur, caeterum prophetandi jus et illas habere jam ostendit, cum mulieri etiam prophetanti velamen imponit, ex lege accipit subjiciendae foeminae auctoritatem, [...] Probet mihi [Marcion], etiam mulierem apud se prophetasse, ex illis suis sanctioribus foeminis, magnidicam". 
w Kościele przy okazji krytyki dwóch znanych prorokiń montanistycznych Maksymilli i Pryscylli:

..Kobieta może być prorokinią, jeżeli wykaże się znakami charyzmatu prorockiego, nic ma prawa jednak przemawiać publicznie na zgromadzeniu ludu"18.

Zdaniem Orygenesa wspomniane montanistki nie spełniły tych dwóch podstawowych warunków: nie wykazały się znakami prorockimi i zabierały glos publicznie. Aleksandryjczyk posługuje się tu argumentacją św. Pawła. Zakaz zabierania głosu na zgromadzeniu przez kobiety jest powtórzeniem slów Apostola: „Kobiety mają na świętych zgromadzeniach milczeć” (1 Kor 14, 34). Natomiast Orygenesowe wyrażenie ,znaki prorockie” przypomina Pawłowe „znaki apostolskie” z 2 Kor 12, 12 („Dowody mojego apostolstwa okazały się pośród was przez wielką cierpliwość, a także przez znaki i cuda, i przejawy mocy") i podobnie jak u Apostoła kryje w sobie najprawdopodobniej wczesnochrześcijańskie kryteria rozpoznawania prawdziwych proroków. Orygenes kryteriów tych nie wymienia, ale np. z Didache wiemy, że należaly do nich: prawowierność, wzorowa moralność i calkowita bezinteresowność ${ }^{19} . \mathrm{Na}$ podstawie powyższej wypowiedzi Orygenesa trudno jednoznacznie stwierdzić, czy były w jego czasach jeszcze jakieś prorokinie ortodoksyjne, czy też odnosił on do wynaturzeń montanistycznych argumenty z czasów św. Pawła. W każdym razie Aleksandryjczyk wykazuje dużą ostrożność wobec charyzmatycznych proroków w Kościele, a działalność kobiet w tym względzie ogranicza bądź do zgromadzeń wyłącznie żeńskich, bądź zupełnie do kręgu prywatnego.

Pozostaje jeszcze do omówienia kwestia stosunku Orygenesa do instytucji diakonis w pierwotnym Kościele. D. Gemmiti stwierdza, na podstawie tekstów źródłowych zachowanych do naszych czasów, że autorzy zachodni z początków III wieku, przede wszystkim Tertulian w Kartaginie i Hipolit w Rzymie, nie wspominają o kobietach zwanych „ministrae"20. Odmiennie kształtuje się sytuacja na Wschodzie, gdzie współcześni wspomnianym pisarzom zachodnim przedstawiciele środowiska aleksandryjskiego - Klemens i Orygenes - poruszają problem diakonis. Orygenes wspomina o nich, komentując następujący tekst św. Pawła z Listu do Rzymian 16, 1-2: „Polecam wam Febę, naszą siostrę, diakonisę Kościoła w Kenchrach. Przyjmijcie ją w Panu tak, jak się świętych

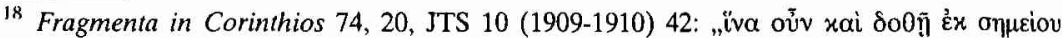

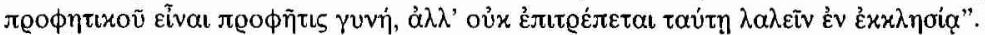

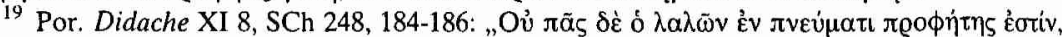

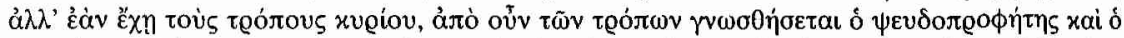

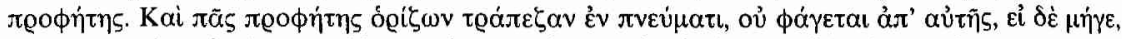

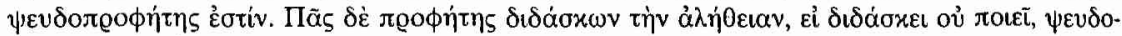

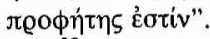

${ }^{20}$ Por. D. Gemmiti, La donna in Origene, Napoli - Roma 1996, 221. Tertulian zresztą przeciwstawia się zdecydowanie sprawowaniu jakichkolwiek funkcji kościelnych przez kobiety. 
winno przyjmować. Wesprzyjcie ją w każdej sprawie, w której pomocy waszej będzie potrzebowała. I ona bowiem wspierała wielu, a także i mnie samego". Aleksandryjczyk rozpoczyna komentarz powyższego tekstu stwierdzeniem, że Paweł „apostolską powagą poucza, że również kobiety ustanawiane są jako diakonisy Kościoła"21. Orygenes porównuje następnie Febe pod względem gościnności do starotestamentalnych postaci Lota i Abrama. Oni za swoją gościnność zasłużyli na przyjmowanie w swoim domu aniołów, ona, wspierając wszystkich, zasłużyła na towarzyszenie samemu Apostołowi Pawłowi i na wspomaganie go. Orygenes kończy swój krótki komentarz istotnym podsumowaniem:

„Powyższy fragment poucza równocześnie o dwóch sprawach: po pierwsze, że, jak wspomnieliśmy, istnieją w Kościele kobiety-diakonisy; po drugie, że do diakonatu powinny przystępować kobiety, które nie tylko wspierały wiele osób, ale swoimi uczynkami zasłużyly także na pochwałę Apostoła".

Na zakończenie Orygenes stwierdza, że uszanowanie należne tym, którzy wypelniają dobre uczynki w Kościele, a więc również diakonisom, ma się wyrażać w zabezpieczeniu ich koniecznych potrzeb, także materialnych.

Uznanie przez Aleksandryjczyka gościnności i posługi na rzecz głosicieli Ewangelii jako podstawowych obowiązków diakonis tak bardzo upodabnia ich funkcję do tej, jaką spełnialy wdowy, że niektórzy uczeni twierdzą, iż w Egipcie w I połowie III w. nie istniał diakonat żeński oddzielony od instytucji wdów i że wszelkie „ministerium" spełniane przez kobiety rozumiano tam jako posługę wdów $^{22}$. Natomiast Gemmiti jest przekonany, że autorzy aleksandryjscy mówiąc o diakonisach, komentują sytuację z czasów św. Pawła, ich wypowiedzi nic mogą więc stanowić wiarygodnego źródla do znalezienia odpowiedzi na pytanie, czy urząd ten przetrwał i czy funkcjonował w Egipcie w ich czasach. W każdym razie, gdy Klemens i Orygenes wspominają o współczesnych im urzędach kościelnych, nie umieszczają diakonis wśród osób pełniących poslugi w Kościele ${ }^{23}$, w przeciwieństwie do wdów, które Orygenes wymienia razem $\mathrm{z}$ biskupami, prezbiterami i diakonami ${ }^{24}$. Czyni tak zapewne ze względu na ich

${ }^{21}$ Commentarium in Romanos X 17, PG 14, 1278A: „[...] apostolica auctoritate docet etiam feminas in ministerio Ecclesiae constitui [...]", thum. S. Kalinkowski, PSP 57/2, 541.

22 Por. R. Kalsbach, Die altkirchliche Einrichtung der Diakonissen bis zu itrem Erlöschen, Freiburg im Breisgau 1926, 95-112.

23 Por. Gemmiti, dz. cyt., s. 227-228.

${ }^{24}$ Por. De oratione $28,4, \operatorname{GCS} 3,377$ : „X

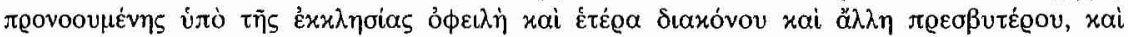

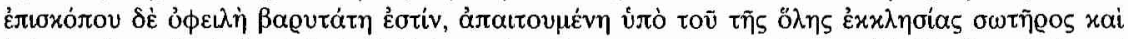

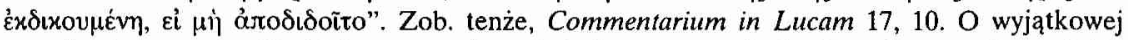
pozycji zajmowanej w Kościele przez wdowy świadczy np. wzmianka Tertuliana w De pudicitia 13, 7, o tym, że grzesznicy, prosząc o pojednanie z Kościolem, musieli skłonić się w obecności całego zgromadzenia przed wdowami i przed prezbiterami. Również Tertulian informuje, że 
obowiązek nauczania kobiet moralności chrześcijańskiej, zbliżający je do nauczycielskiego zadania członków hicrarchii ${ }^{25}$.

Na zakończenie należy stwierdzić, że zachowane teksty Orygenesa nie są idealnym źródłem historycznym, które można wykorzystać bez zastrzeżeń do rekonstrukcji roli świeckich w Kościele III wieku. Zgodnie z sugestiami D. Gemnitiego, wypowiedzi Aleksandryjczyka, zwłaszcza o udziale kobiet w funkcjach kościelnych, odnoszą się w większości nie tyle do wspólczesnej Orygenesowi sytuacji panującej w Egipcie, ile do czasów, w których żył i pisal św. Paweł, i mają charakter bardziej egzegetyczno-teologiczny niż historyczny.

Jeśli chodzi o osobisty stosunek naszego autora do problemu pełnienia przez świeckich pewnych funkcji, które współcześnie są zastrzeżone kapłanom urzędowym lub zbliżone do ich posługi, to odnosił się on do tego zjawiska $z$ umiarkowaniem i nie bez zastrzeżeń, chociaż pobieżna lektura jego dzieł mogłaby prowadzić i rzeczywiście prowadziła już badaczy do przeciwnego wniosku. Orygenes zezwalał świeckim ludziom duchowym na prowadzenie poradnictwa duchowego, zastrzegal jednak biskupom i prezbiterom udzielanie odpuszczenia grzechów i nakładanie pokuty, zgodnie $z$ ówczesną praktyką Kościoła. Pelnienie funkcji kościelnych przez kobiety dopuszczał pod pewnymi warunkami: prorokinie mogły prorokować tylko prywatnie, a nie na zgromadzeniu; diakonisy powinny ograniczyć swoją służbę do praktyki gościnności; wdowy miały nauczać chrześcijańskiej moralności, ale ich posługa mogła odnosić się jedynie do przedstawicielek tej samej płci. Nie wiemy, co Orygenes sądził na temat głoszenia homilii przez osoby nie będące biskupami ani prezbiterami. Jest to jedyna $\mathrm{z}$ funkcji, przysługujących w naszych czasach kapłanom, na temat której nie pozostał ślad w zachowanych po nim pismach, a zarazem jedyna $z$ omawianych powyżej, którą, na ile pozwalają to stwierdzić źródła, Orygenes wypełniał osobiście jeszcze przed przyjęciem święceń kapłańskich.

podczas celebracji Eucharystii wdowy zajmowały specjalne miejsca (De virginibus velandis 9,3 ) i stały pókkolem wokół biskupa (Exhortatio in castitatem 11,2 ). Z innych źródel dowiadujemy się o ich obowiązkach: modlitwie, szczególnie za chorych i grzeszników (1 Tm 5, 5; Hippolytus, Traditio Apostolica 10; 23; Didascalia et Constitutiones Apostolorum III 5, 2; 8, 1-3), oraz poście (Hippolytus, Traditio Apostolica 23).

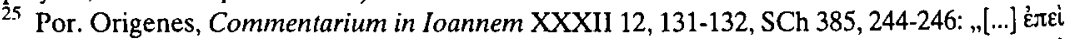

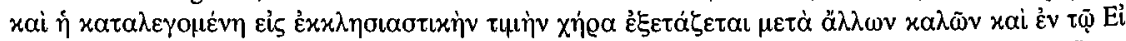

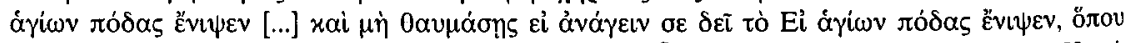

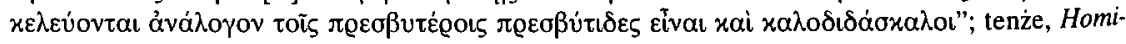
liae in Isaiam 6, 3; tenże, Commentarium in Romanos X 20. 


\section{LA PARTICIPATION DES LAÏCS AUX STRUCTURES INSTITUTIONNELLES \\ DE L'ÉGLISE ET AUX FONCTIONS RÉSERVÉES AUJOURD'HUI AU CLERGÉ SELON ORIGÈNE}

(Resumé)

L'auteur d'article analyse quelques textes d'Origène concernants la participation éventuelle des laïcs aux fonctions suivantes réservées aujourd'hui au clergé: la proclamation publique des commentaires de la Bible pendant la liturgie; l'absolution des péchés, l'imposition de la pénitence et la direction spirituelle; le ministère des prophetesses et de diaconesses.

Le point de vue d'Origène était assez modéré. Il permettait aux laïss, qui sont les hommes spirituels, d'accompagner spirituellement des autres, mais il réservait strictement aux évêques et prêtres l'absolution des péchés et l'imposition de la pénitence, à l'accord avec la pratique de l'Église à cette époque. Il permettait aux femmes d'accomplir certaines fonctions ecclésiastiques, mais sous les conditions suivantes: les prophetesses ne pouvaient prophetiser qu'à titre privé; les diaconesses devaient limiter son service à la pratique de l'hospitalité; les veuves étaient obligées à enseigner la moral chrétienne, mais leur enseignement pouvait être dirigé seulement vers les femmes. On ne connait pas le point de vue d'Origène sur la proclamation d'homélies par les laïcs. C'était pourtant la fonction unique parmi ceux, qui sont réservées aujourd'hui au clergé, à quelle il participait personnellement. Mais il n'a laissé aucune trace de son opinion sur cette pratique dans ces ouvres que nous possédons aujourd'hui.

Les textes d'Origène ne constituent pas une source historique idéale, qu'on pourrait exploiter sans limites pour la reconstruction de la place des laïcs à l'Église du $\mathrm{III}^{\mathrm{e}}$ siècle. Ses constatations, spécialement sur la participation des femmes aux fonctions ecclésiastiques, concernent plutot l'époque de saint Paul et non la situation d'Égypte aux temps d'Origène. À part cela elles ont caractère plus exégétique et théologique que historique. 